Bradbury, Mark (2011) "Representative Bureaucracy: Assessing Current and Additional Evidence of Active Representation." American Review of Public Administration, vol. 41, num. 2 ( March 2011), with J. Edward Kellough. Published by Sage. doi: 10.1177/0275074010367823 [ISSN: 0275-0740]

\title{
Representative Bureaucracy: Assessing the Evidence on Active Representation
}

\author{
Mark Bradbury and J. Edward Kellough
}

\begin{abstract}
The theory of representative bureaucracy suggests that a public workforce representative of the people in terms of race, ethnicity, and sex will help ensure that the interests of all groups are considered in bureaucratic decision-making processes. The theory posits that the active representation of group interests occurs because individual bureaucrats reflect the views of those who share their demographic backgrounds. Research in the public administration literature, however, includes only a relatively small number of studies providing evidence consistent with active representation. In addition, that literature is, for the most part, composed of studies that are conducted at an organizational level, making it impossible for us to draw inferences about the behavior of individual bureaucrats without committing an ecological fallacy. Researchers in the field of criminal justice studies, on the other hand, have long tested the relationship between workforce demography and government outcomes and have done so at the individual level and in contexts that allow confidence that the outcomes observed are indeed the product of action by minority or female public servants. Those studies are reviewed, and their findings provide the first definitive evidence of a connection between the presence of diversity in the public workforce and the representation of minority interests.
\end{abstract}

\section{Keywords}

representative bureaucracy, active representation, criminal justice 
The power of government bureaucracies to formulate and shape public policies, due in no small part to the legitimate exercise of bureaucratic discretion in administrative decision making, is widely acknowledged and understood (see, e.g., Chaney \& Saltzstein, 1998; Lipsky, 1980; MaynardMoody \& Musheno, 2003; Meier, 2000; Rourke, 1984; Sowa \& Selden, 2003). Such discretionary authority is, in fact, crucial to the effective operation of public organizations. But bureaucratic power also poses a significant dilemma. How are governments, especially governments grounded on democratic principles, to control the exercise of bureaucratic authority over public policy, particularly when public bureaucrats have substantial expertise and constituency support? This is one of the most central and enduring questions within the study of public administration (Rourke, 1984). Although numerous mechanisms of control are available-including executive, legislative, and judicial oversight; public scrutiny; and adherence to administrative ethics (see Meier, 2000)bureaucratic power and discretion remain essential aspects of government.

For this reason, scholars have long argued that a useful additional means for ensuring the responsible use of bureaucratic discretion is achieved when the attitudes, values, and opinions of bureaucrats represent, in the aggregate, those of the people governed (Kingsley, 1944; Long, 1952; Van Riper, 1958). Through this mechanism, bureaucratic policy processes become more inclusive, and the power of the bureaucracy is better reconciled with the requirements of democracy. The bureaucracy, in effect, becomes a representative organization that may supplement the representation provided through other political institutions including elected legislatures (Krislov \& Rosenbloom, 1981; Selden, Brudney, \& Kellough, 1998). This is the idea behind the theory of representative bureaucracy and, in particular, the concept of active representation first articulated by Frederick C. Mosher in 1968.

\section{The Theory of Representative Bureaucracy}

Mosher (1968) argued that a bureaucracy can be representative in two ways. First, passive representation occurs when an organization includes individuals from specified groups, such as racial or ethnic minorities and women, within its ranks. Thus, a bureaucracy is passively representative to the extent that it employs minorities and women in numbers proportionate to their shares of the population, or at least proportionate to those parts of the population with qualifications requisite for employment. Researchers have focused precisely on the extent to which passive representation occurs, the determinants of that representation across government departments and agencies, and the real and perceived benefits of that representation (e.g., Cayer \& Sigelman, 1980; Cornwell \& Kellough, 1994; Dolan, 2000, 2002; Goode \& Baldwin, 2005; Hsieh \& Winslow, 2006; Kellough, 1990; Kellough \& Elliott, 1992; Kelly \& Newman, 2001; Krislov, 1974; Lewis, 1988; Llorens, Wenger, \& Kellough, 2008; Naff \& Crum, 2000; Riccucci, 2009; Riccucci \& Saidel, 1997; Theobald \& Haider-Markel, 2008; Thielemann \& Stewart, 1996).

The second type of representation identified by Mosher (1968) is observed when a bureaucrat "press[es] for the interests and desires of those whom he is presumed to represent" (p. 11). This is the concept labeled active representation. It implies that bureaucrats will act, either consciously or unconsciously, to see that the interests of individuals who share their group identities are not overlooked when policy-relevant decisions are made. Active representation occurs, it is theorized, because bureaucrats share core attitudes, values, and beliefs with the social groups from which they are drawn. Their views are the product of common socialization experiences shaped in important ways by, for example, racial, ethnic, and gender identities. The theory of representative bureaucracy suggests that when bureaucrats exercise discretionary authority, their decisions are a function, in part, of the attitudes, values, and beliefs they have formed on the basis of their social backgrounds (Krislov \& Rosenbloom, 1981; Meier, 1993a; Saltzstein, 1979). In other words, passive representation is expected to lead to active representation.

Given its importance as a mechanism for bureaucratic responsiveness, it is interesting to note that representative bureaucracy, and specifically the connection between passive and active representation, has been subjected to empirical investigation by only a relatively small number of public administration scholars (see, e.g., Hindera, 1993a, 1993b; Keiser, Wilkins, Meier, \& Holland, 2002; Meier, 1993b; Meier \& Nicholson-Crotty, 2006; Meier \& Stewart, 1992; Meier, Stewart, \& England, 1990; Selden, 1997a, 1997b; Selden, Brudney, \& Kellough, 1998; Wilkins \& Keiser, 2006; 
Wilkins \& Williams, 2008). In these works, researchers typically look for positive associations between the presence of minority or female bureaucrats within public organizations and bureaucratic out- comes consistent with the interests of those groups.

\section{Evidence for Active Representation in the Public Administration Literature}

One of the earliest works to test empirically for active representation within public organizations examined educational outcomes in U.S. public school districts (Meier et al., 1990). The study included all districts in the country with at least 15,000 students and for which at least $1 \%$ of the enrollment comprised African Americans. The authors found that African American students were disproportionately and inequitably segregated into lower ability tracks and subjected to disciplinary measures, but as the presence of African American teachers increased across districts, the inequities suffered by African American students decreased. Similar results were found in subsequent studies focused on public schools in Florida (Meier, 1993b; Meier \& Stewart, 1992).

In related research, Hindera (1993a, 1993b) examined the passive representation of African Americans, Latinos, and women among equal employment opportunity investigators in District Offices of the Equal Employment Opportunity Commission and the possible connections between that representation and the percentage of total charges filed on behalf of members of those groups. Hindera found evidence that could be indicative of active representation by African American and Latino investigators but no apparent or observable active representation by women. A more recent analysis of Equal Employment Opportunity Commission data, however, revealed that the introduction of new goals and priorities in the agency since the time of the Hindera studies may have diminished the presence of active representation by African Americans (Meier, Pennington, \& Eller, 2005). Subsequent works to examine these issues were by Selden (1997a, 1997b) and Selden, Brudney, and Kellough (1998). These works focused on the Farmer's Home Administration (FmHA) Rural Housing Loan Program within the U.S. Department of Agriculture, which provided loans for the construction and rehabilitation of rural housing. In general, the indication was that FmHA Districts with larger proportions of county supervisors who were African American awarded larger proportions of their loans to African American loan applicants, even while controlling statistically for a broad range of district characteristics. Comparable results were found regarding the representation

of Hispanics and Asian Americans.

In other aspects of this work, the unit of analysis was shifted to the level of the individual bureaucrat through a survey of FmHA county supervisors in 10 southern states. The survey requested information on a variety of demographic characteristics of each supervisor and on the extent to which the supervisors believed that they should work to represent minority interests. Results showed that adherence to a "minority representative role" was a strong predictor of the proportion of loan decisions made by individual supervisors in favor of minority applicants (see Selden, 1997a; Selden, Brudney, Kellough, 1998). Nevertheless, the findings did not isolate active representation by minority bureaucrats because nonminority county supervisors as well as minority supervisors adhered to the minority representative role, and it was that role adherence, rather than race/ethnicity, that led to increases in decisions favoring minority loan applicants.

More recent work has focused on the representation of women's interests rather than minority interests. Keiser et al. (2002), for example, found that higher levels of representation of women among math teachers and among teachers in general was positively associated with improved math scores for female students on standardized tests. Additionally, Wilkins and Keiser (2006) found results consistent with active representation by women in supervisory positions in child support-enforcement agencies in Missouri, and Meier and Nicholson-Crotty (2006) found that higher proportions of female police officers in law enforcement agencies in large metropolitan 
counties in the United States were positively associated with reports for sexual assaults on women and arrests for those assaults.

Additional recent studies at an organizational level have examined racial profiling behavior by police officers, that is, the practice of law enforcement officers concluding that certain individuals identified by their minority racial or ethnic status are more likely than other people to be violating the law (Wilkins \& Williams, 2008, 2009). The first of these studies (Wilkins \& Williams, 2008) found that a higher percentage of African American police officers within police districts led to an increase in racial profiling of African American citizens. Similarly, in the 2009 study, the authors found that as the proportion of Latino officers increased across police districts, the racial profiling of Latino drivers increased.

\section{Evidence of Active Representation, Reassessed}

In general, a review of the public administration literature on representative bureaucracy reveals considerable evidence consistent with the expected linkage between passive and active representation. With the exception of recent work by Wilkins and Williams (2008, 2009), it appears that the presence of minority group members within specified public bureaucracy settings is positively associated with bureaucratic outcomes consistent with the interests of members of those groups. Analogous results are found in studies examining the representation of women and their interests, particularly when the issues examined are "gendered" or highly salient to women (Keiseret al., 2002; Keiser \& Wilkins, 2006). In short, we know that certain public organizations with larger proportions of women and/or minorities in decision-making roles are more likely to produce outcomes compatible with the interests of women and/or minorities than similar organizations with fewer women and/or minorities.

Nevertheless, as Lim (2006) and others (see Meier \& Nicholson-Crotty, 2006) remind us, bureaucratic results favorable to the interests of minorities or women may be the product of factors other than active representation by minority or female bureaucrats. For example, it is possible that those outcomes are produced by nonminority bureaucrats who have been sensitized to minority or women's interests through the presence of minority or female coworkers. Indeed, as noted above, Selden (1997a, 1997b) found evidence that nonminority bureaucrats as well as minority bureaucrats assumed a "minority representative role" while at work (in addition, see Bradbury \& Kellough, 2008; Selden et al., 1998).

It may also be the case that the presence of minorities and women in the public workforce affects client behavior, irrespective of any action taken by the bureaucrat, and that the altered client behavior produces outcomes consistent with their interests. Notably, Meier and Nicholson-Crotty (2006) suggested that their findings, demonstrating that the presence of female police officers was positively associated with reports by female victims of sexual assault and arrests for sexual assault, were, in part, the result of a greater willingness of female victims to report crimes to female officers. Recent work by Dee $(2004,2005)$ further highlights this issue. Dee found that minority public school students, for example, performed better when they were placed with minority teachers and that female students performed better when they were in classrooms with female teachers, but Dee cautioned that those results were not necessarily caused by specific actions by the teachers (i.e., active representation) but may instead have been caused by changes in students' expectations, motivation levels, and effort when they were in classrooms with teachers who shared their racial or ethnic identities. Studies in which organizations are the units of analysis may detect outcomes reflective of minority and/or female interests produced by a variety of means. We cannot infer from an organizational-level analysis, however, anything definitive about the behavior of individual bureaucrats. To do so would be to commit an ecological fallacy. ${ }^{1}$ When data on representation and decision making are aggregated to an organizational level, we cannot know with certainty whether outcomes observed 
are produced by active representation or are the result of other mechanisms. To isolate the impact of active representation by minority and/or female bureaucrats, we need studies in which individual bureaucrats are the units of analysis; the impact of their racial, ethnic, or gender identities on their decisions is isolated and observed; and bureaucratic outcomes are not the result of coproduction in the sense that both the bureaucrats and their clients have independent effects on those outcomes. These kinds of studies are largely absent from the public administration literature on representative bureaucracy. ${ }^{2}$ Research from the field of criminal justice, however, includes a number of studies providing direct evidence of active representation. ${ }^{3}$

\section{An Examination of Literature From the Field of Criminal Justice Studies}

Although professional practice within the criminal justice system lies within the boundaries of public administration generally, the criminal justice literature and academic journals are largely distinct from those of public administration, and researchers within the two fields do not frequently cite each other. Nevertheless, many scholars interested in the operation of the criminal justice system have hypothesized that the behavior of police officers, criminal courts judges, and corrections officials will be consistent with predictions from the theory of representative bureaucracy.

\section{Literature Focused on Policing}

It has long been understood that the individual dispositions of police officers will influence their behaviors on the job. Directly relevant to our investigation, two recent studies by Close and Mason (2006, 2007) provide strong evidence of a positive relationship between the presence of minority officers and the active representation of minority interests. Both studies analyze data from traffic stops by individual state police officers in Florida from January 2000 to May 2002. For each traffic stop, characteristics of the individual trooper and the driver were recorded along with the circumstances leading to the stop. In the 2006 study, the authors found that minority drivers, both African American and Latino, received more favorable treatment from minority officers than from White officers regarding charges and equipment violations. In fact, the authors found evidence of discrimination against minority drivers by White officers. In the study published in 2007, the authors found that the race and ethnicity of the officers also influence decisions to search the vehicles of minority drivers. African American drivers, for example, were almost 5 times more likely to be searched by a White officer than by an African American officer, and Latino drivers were 2.5 times more likely to be searched by a White officer than by a Latino officer. These studies provide substantial evidence of active representation by minority state police officers. Because the unit of analysis focuses on the behavior of individual officers, actions by White and minority officers are separately identified. Behavior by White officers is not confounded with any active representation by the minority officers, as could be the case in organizational-level studies. Additionally, although there is interaction between the officer and the driver during a traffic stop, there is no coproduction of the outcome in the sense of each party having an independent effect. The outcome is entirely at the discretion of the officer.

Similar findings were reported by Gilliard-Matthews, Kowalski, and Lundman (2008) using data drawn from nationwide citizen surveys from 1992 and 2002 focusing on contacts between police and the public. In these surveys, respondents were asked if they had been stopped by police while driving in the past 12 months. Respondents who answered affirmatively were then asked additional questions about the most recent time they were stopped and if that stop resulted in a ticket being issued. The authors found that minority drivers were significantly more likely to be ticketed by White officers than by African American officers. 
Other work, however, has produced different results. Anbarci and Lee (2008), for example, analyzed traffic stops resulting in the issuance of speeding tickets by individual police officers in the city of Boston from April 2001 to November 2002. The researchers were interested in a phenomenon called speed discounting, whereby police officers use their discretion to record a lower speed on a ticket than was actually observed in order to reduce the severity of the associated punishment. When examining the distribution of speeding tickets in their sample, the authors found a huge spike in the number of tickets (more than $30 \%$ of the total of 25,738 ) issued for violations of exactly 10 miles per hour over the posted limit. The authors assumed that drivers who were ticketed for driving at exactly 10 miles per hour over the limit were the recipients of speed discounting. The analysis then indicated that minority officers, particularly African American officers, were less likely than White officers to engage in speed discounting overall, but they were even less inclined to be lenient to minority drivers than they were to be lenient to nonminority drivers. It must be noted, however, that the authors did not control in the analysis for information that officers might take into consideration when issuing tickets such as the driving record of the ticketed motorist or the possibility that minority officers may patrol areas of the city with larger proportions of minority drivers with poor records.

In related work, Brown and Frank (2006) used "systematic social observations" of officers in Cincinnati to directly record individual-level data on arrests. They found that although White officers were more likely to make arrests than Black officers, the probability that a Black suspect will be arrested was higher when encountering a Black officer than when encountering a White officer (98\% to 93\%, respectively). Thus, according to the authors, the "evidence points to an interpretation that black officers are more coercive toward black citizens when it comes to use of their arrest powers” (p. 120).

Work by Sun and Payne (2004) provides additional insight. These researchers examined 3,130 distinct encounters between individual police officers and individual criminal suspects in Indianapolis and St. Petersburg. Each encounter was coded by trained observers for the degree of disrespect shown toward the suspect. The authors found that African American officers were more likely than White officers to conduct supportive activities in predominantly African American neighborhoods, but they were also more coercive generally than White officers in their response to interpersonal conflicts. Using the "blue cop" and "black cop" metaphors to represent police and personal socialization experiences, respectively, Sun and Payne observed that "decisions to perform traditional law enforcement functions (e.g., using force, arresting, and maintaining order) seem to be congruent with the blue cop identity whereas decisions to perform supportive activities are congruent with identities that show concern about their community” (pp. 535-536).

Overall, from the individual-level work on policing, we can conclude that active representation by minority officers does occur in several contexts. In addition, when research findings indicate that African American officers are tougher than White officers on African American citizens, it is not necessarily the case that African American officers are acting in a manner inconsistent with the interests of the Black community. Strict enforcement exercised by African American police officers on Black suspects may benefit black victims, neighborhoods, and communities.

\section{Literature Focused on the Courts}

Courts sit at the center of the criminal justice system. Obviously, they are located within the judicial branch of government, rather than the executive, and are not part of what is normally thought of as the public bureaucracy. ${ }^{4}$ Nevertheless, important questions can be raised as to whether minority judges provide active representation of minority interests, and several studies exist that examine the impact of race, ethnicity, and sex on the sentencing decisions of individual criminal courts judges. 
Welch, Combs, and Gruhl (1988), for example, examined the sentences handed down by individual judges in a large northeastern city from 1968 to 1979. The authors found that White judges were more likely to send African American defendants to prison than they were to send white defendants to prison. At the same time, however, there were no racial differences in the sentencing patterns of African American judges. In the authors' words, "black judges tend to treat black and white defendants alike" regarding the decision to incarcerate, "while white judges are more severe with blacks" (p. 133). The researchers concluded that "black judges provide more than symbolic representation" to African Americans and served to "equalize the criminal justice system's treatment of black and white defendants” (p. 134).

A similar analysis of African American and White judges was conducted by Spohn (1990) for cases involving violent felonies in Detroit city courts. On the issue of incarceration rates, Spohn found that "Black judges are less likely than white judges to sentence black offenders to prison" (p. 1208; see also Johnson, 2007). Although statistically significant, however, the difference between Black and White judges in sentencing rates for Black offenders was actually quite small (72.9\% and $74.2 \%$, respectively). Similar patterns were also found for Hispanic defendants in works by Holmes, Hosch, Daudistel, Perez, and Graves (1993) and Wooldredge (1998).

The pattern that emerges from these studies is that minority judges do actively represent minority interests, and they appear to do so by working to ensure fairness within the criminal justice system. Contrary to arguments offered by Lim (2006), the active representation of minority interests by minority officials need not be equated with bias. It may, in fact, operate to ensure justice. All judges are heavily socialized to follow the law and established precedent, but sentencing discretion exists, and in exercising that discretion, minority judges are apparently aware of the interests of the minority community.

\section{Literature Focused on Corrections Systems}

Our corrections systems house offenders who have been ordered to be incarcerated. There is less evidence related to active representation by minority or female corrections officials, however, than is found in the literatures on policing and the courts. Nevertheless, two studies have controlled for race in the examination of the attitudes of correctional officers toward inmates. In the first, Jackson and Ammen (1996) found that "non-Caucasian officers will tend to possess the ability to demonstrate greater identification with inmates resulting from similar or common backgrounds and/or socialization experiences” (p. 154). This finding, which implies that active representation is occurring, could lend greater urgency to efforts to diversify the corrections workforce in light of the disproportionately large number of minority inmates within corrections facilities. In the other work, Mitchell, MacKenzie, Gover, and Styve (2001) surveyed the attitudes of juvenile corrections officers toward inmates and obtained comparable results. Specifically, the authors found that African American staff members were more empathetic toward the inmates (who were disproportionately minority) and "were more likely . . . to believe that the criminality of juvenile offenders was due to poor parenting or a result of having had a 'tough life”" (p. 73).

\section{Conclusion}

The behavior of individual bureaucrats was the focus of Mosher's (1968) definition of active representation. But as noted earlier, studies relying on data aggregated to an organizational level, as is currently typical in the public administration literature, cannot separate the effects of the behavior of minority or female bureaucrats from that of nonminority or male bureaucrats or clients. Policy outcomes consistent with minority interests or the interests of women may be produced by nonminority bureaucrats, for example, following their interactions with minority colleagues. 
Furthermore, whenever outcomes are coproduced, that is, when bureaucrats and clients each have independent effects on those outcomes, client effects may be partially responsible for organizational patterns observed. At best, analyses relying on organizational-level data can be said to provide evidence consistent with active representation. Only those research designs that employ measures of the individual behavior of public workers, such as those found in the criminal justice literature, can separate the behavior of minority or female bureaucrats from that of nonminority bureaucrats or men. In addition, the criminal justice literature provides research from contexts in which independent client effects are either absent or minimized. As a result, the criminal justice literature provides some of the strongest evidence to date in support of the theory of representative bureaucracy. For this reason, it is imperative that the criminal justice studies reviewed here be included in discussions of representative bureaucracy. It is always prudent for researchers from one academic field to be cognizant of related work in other fields, and the examples provided here serve well to underscore that point.

Further development of this line of inquiry should continue to take place with the field of public administration. We view the literature on representative bureaucracy within public administration as having developed through three major streams to this point. Studies on attitude congruence between minority bureaucrats and minorities in the general population appeared early followed by studies of passive representation and its determinants. Later, we saw the rise of studies of the linkage between passive and active representation with organizations or their subdivisions as the units of analysis. We believe that a new stream or generation of academic research is now needed within the public administration focusing at the individual level on the connection between passive and active representation. The literature reviewed here from the field of criminal justice provides a valuable model for that work.

\section{Declaration of Conflicting Interests}

The author(s) declared no conflicts of interest with respect to the authorship and/or publication of this.

\section{Funding}

The author(s) received no financial support for the research and/or authorship of this article.

\section{Notes}

1. An ecological fallacy occurs when behavior observed at the group or aggregate level is assumed to hold for individuals who belong to that group.

2. We note that individual public servants were the units of analysis in recent work by Wilkins (2007), where it was found that female child support enforcement supervisors had different priorities than their male counterparts and were more sympathetic to efforts to increase child support benefits to divorced mothers.

3. Also, we examined the literatures of disciplines besides criminal justice that could be related back to public administration, including public health and public education, but could not identify studies that provided tests of active representation using individual-level data. Furthermore, as the number of studies in criminal justice that use individual-level data is too small to conduct a true meta-analysis, we briefly review each study independently.

4. The reader is reminded, however, that Lipsky (1980) includes judges in his classic analysis of street-level bureaucrats.

\section{References}

Anbarci, N., \& Lee, J. (2008). Speed discounting and racial disparities: Evidence from speeding tickets in Boston (Discussion Paper No. 3903). Bonn, Germany: Institute for the Study of Labor.

Bradbury, M. D., \& Kellough, J. E. (2008). Representative bureaucracy: Exploring the potential for active representation. Journal of Public Administration Research and Theory, 18, 697-714. 
Brown, R. A., \& Frank, J. (2006). Race and officer decision making: Examining differences in arrest outcomes between black and white officers. Justice Quarterly, 23, 96-126.

Cayer, N. J., \& Sigelman, L. (1980). Minorities and women in state and local government: 1973-1975. Public Administration Review, 40, 443-450.

Chaney, C. K., \& Saltzstein, G. H. (1998). Democratic control and bureaucratic responsiveness: The police and domestic violence. American Journal of Political Science, 42, 745-768.

Close, B. R., \& Mason, P. L. (2006). After the traffic stops: Officer characteristics and enforcement actions. Topics in Economic Analysis \& Policy, 6, 1-41.

Close, B. R., \& Mason, P. L. (2007). Searching for efficient enforcement: Officer characteristics and racially biased policing. Retrieved from http://www.bepress.com/rle/vol3/iss2/art5

Cornwell, C., \& Kellough, J. E. (1994). Women and minorities in federal government agencies: Examining evidence from panel data. Public Administration Review, 54, 265-270.

Dee, T. S. (2004). Teachers, race, and student achievement in a randomized experiment. Review of Economics and Statistics, 86, 195-210.

Dee, T. S. (2005). A teacher like me: Does race, ethnicity, or gender matter? American Economic Review, 95, 158-165.

Dolan, J. A. (2000). The senior executive service: Gender, attitudes, and representative bureaucracy. Journal of Public Administration Research and Theory, 10, 513-529.

Dolan, J. A. (2002). Representative bureaucracy in the federal executive: Gender and spending priorities. Journal of Public Administration Research and Theory, 12, 353-375.

Gilliard-Matthews, S., Kowalski, B. R., \& Lundman, R. J. (2008). Officer race and citizen-reported traffic ticket decisions by police in 1999 and 2002. Police Quarterly, 11, 202-219.

Goode, S. J., \& Baldwin, J. N. (2005). Predictors of African American representation in municipal government. Review of Public Personnel Administration, 25, 29-55.

Hindera, J. J. (1993a). Representative bureaucracy: Imprimis evidence of active representation in EEOC district offices. Social Science Quarterly, 74, 95-108.

Hindera, J. J. (1993b). Representative bureaucracy: Further evidence of active representation in EEOC district offices. Journal of Public Administration Research and Theory, 3, 415-429.

Holmes, M. D., Hosch, H. M., Daudistel, H. C., Perez, D. A., \& Graves, J. B. (1993). Judges’ ethnicity and minority sentencing: Evidence concerning Hispanics. Social Science Quarterly, 74, 496-506.

Hsieh, C.-W., \& Winslow, E. (2006). Gender representation in the federal workforce. Review of Public Personnel Administration, 26, 276-294.

Jackson, J. E., \& Ammen, S. (1996). Race and correctional officers' punitive attitudes toward treatment programs for inmates. Journal of Criminal Justice, 24, 153-166.

Johnson, B. D. (2007). Judges on trial: A reexamination of judicial race and gender. Effects across modes of conviction. Paper presented at the Association for Public Policy Analysis and Management Conference, Washington, DC.

Keiser, L. R., Wilkins, V. M., Meier, K. J., \& Holland, C. A. (2002). Lipstick and logarithms: Gender, institutional context, and representative bureaucracy. American Political Science Review, 96, 553-564.

Kellough, J. E. (1990). Integration in the public workplace: Determinants of minority and female employment in federal agencies. Public Administration Review, 50, 557-566.

Kellough, J. E., \& Elliott, E. (1992). Demographic and organizational influences on racial/ethnic and gender integration in federal agencies. Social Science Quarterly, 73, 1-11.

Kelly, R. M., \& Newman, M. (2001). The gendered bureaucracy: Agency mission, equality of opportunity, and representative bureaucracy. Women \& Politics, 22, 1-33.

Kingsley, J. D. (1944). Representative bureaucracy: An interpretation of the British civil service. Yellow Springs, OH: Antioch Press.

Krislov, S. (1974). Representative bureaucracy. Englewood Cliffs, NJ: Prentice Hall.

Krislov, S., \& Rosenbloom, D. H. (1981). Representative bureaucracy and the American political system. New York, NY: Praeger. 
Lewis, G. B. (1988). Progress toward racial and sexual equity in the federal civil service? Public Administration Review, 48, 700-706.

Lim, H.-H. (2006). Representative bureaucracy: Rethinking substantive effects and active representation. Public Administration Review, 66, 193-204.

Lipsky, M. (1980). Street-level bureaucracy: Dilemmas of the individual in public Services. New York, NY: Russell Sage Foundation.

Llorens, J. J., Wenger, J. B., \& Kellough, J. E. (2007). Choosing public sector employment: The impact of wages on the representation of women and minorities in state bureaucracies. Journal of Public Administration Research and Theory, 18, 397-413.

Long, N. (1952). Bureaucracy and constitutionalism. American Political Science Review, 46, 808-818.

Maynard-Moody, S., \& Michael, M. (2003). Cops, teachers, counselors: Stories from the front lines of public service. Ann Arbor: University of Michigan Press.

Meier, K. J. (1993a). Representative bureaucracy: A theoretical and empirical exposition. Research in Public Administration, 2, 1-35.

Meier, K. J. (1993b). Latinos and representative bureaucracy: Testing the Thompson and Henderson hypotheses. Journal of Public Administration Research and Theory, 3, 393-414.

Meier, K. J. (2000). Politics and the bureaucracy: Policymaking in the fourth branch of government (4th ed.). Fort Worth, TX: Harcourt College.

Meier, K. J., \& Nicholson-Crotty, J. (2006). Gender, representative bureaucracy, and law enforcement: The case of sexual assault. Public Administration Review, 66, 850-860.

Meier, K. J., Pennington, M. S., \& Eller, W. S. (2005). Race, sex, and Clarence Thomas: Representation change in the EEOC. Public Administration Review, 65, 171-179.

Meier, K. J., \& Stewart, J. J., Jr. (1992). The impact of representative bureaucracies: Educational systems and public policies. American Review of Public Administration, 22, 157-171.

Meier, K. J., Stewart, J., Jr., \& England, R. E. (1990). Race, class, and education: The politics of secondgeneration discrimination. Madison: University of Wisconsin Press.

Mitchell, O., MacKenzie, D. L., Gover, A. R., \& Styve, G. J. (2001). The influence of personal background on perceptions of juvenile correctional environments. Journal of Criminal Justice, 29, 67-76.

Mosher, F. C. (1968). Democracy and the public service. Oxford, England: Oxford University Press.

Naff, K. C., \& Crum, J. (2000). The president and representative bureaucracy: Rhetoric and reality. Public Administration Review, 60, 98-110.

Riccucci, N. M. (2009). The pursuit of social equity in the federal government: A road less traveled? Public Administration Review, 69, 373-382.

Riccucci, N. M., \& Saidel, J. R. (1997). The representatives of state-level bureaucratic leaders: A missing piece of the representative bureaucracy puzzle. Public Administration Review, 57, 423-431.

Rourke, F. E. (1984). Bureaucracy, politics, and public policy (3rd ed.). Boston, MA: Little, Brown.

Saltzstein, G. H. (1979). Representative bureaucracy and bureaucratic responsibility: Problems and prospects. Administration and Society, 10, 464-475.

Selden, S. C. (1997a). The promise of representative bureaucracy: Diversity and responsiveness in a government agency. Armonk, NY: M. E. Sharpe.

Selden, S. C. (1997b). Representative bureaucracy: Examining the linkage between passive and active representation in the Farmers home administration. American Review of Public Administration, 27, 22-42.

Selden, S. C., Brudney, J. L., \& Kellough, J. E. (1998). Bureaucracy as a representative institution: Toward a reconciliation of bureaucratic government and democratic theory. American Journal of Political Science, 42, 717-744.

Sowa, J. E., \& Selden, S. C. (2003). Administrative discretion and active representation: An expansion of the theory of representative bureaucracy. Public Administration Review, 63, 700-710.

Spohn, C. (1990). The sentencing decisions of black and white judges: Expected and unexpected similarities. Law \& Society Review, 24, 1197-1216. 
Sun, I. Y., \& Payne, B. K. (2004). Racial differences in resolving conflicts: A comparison between black and white police officers. Crime \& Delinquency, 50, 516-541.

Theobald, N. A., \& Haider-Markel, D. P. (2008). Race, bureaucracy, and symbolic representation: Interactions between citizens and police. Journal of Public Administration Research and Theory, 19, 409-426.

Thielemann, G. S., \& Stewart, J., Jr. (1996). A demand-side perspective on the importance of representative bureaucracy: AIDS, ethnicity, gender, and sexual orientation. Public Administration Review, 56, 168-173.

Van Riper, P. (1958). History of the United States civil service. New York, NY: Harper \& Row.

Welch, S., Combs, M., \& Gruhl, J. (1988). Do black judges make a difference? American Journal of Political Science, 32, 126-136.

Wilkins, V. M., \& Keiser, L. R. (2006). Linking passive and active representation by gender: The case of child support agencies. Journal of Public Administration Research and Theory, 16, 87-102.

Wilkins, V. M. (2007). Exploring the causal story: Gender, active representation, and bureaucratic priorities. Journal of Public Administration Research and Theory, 17, 77-94.

Wilkins, V. M., \& Williams, B. N. (2008). Black or blue: Racial profiling and representative bureaucracy. Public Administration Review, 68, 654-664.

Wilkins, V. M., \& Williams, B. N. (2009). Representing blue: Representative bureaucracy and racial profiling in the Latino community. Administration \& Society, 40, 775-798.

Wooldredge, J. D. (1998). Analytical rigor in studies of disparities in criminal case processing. Journal of Quantitative Criminology, 14, 155-179.

\section{Bios}

Mark Bradbury is Assistant Professor in the Department of Government and Justice Studies at Appalachian State University. Dr. Bradbury has published in numerous journals including the Journal of Public Administration Research and Theory and Review of Public Personnel Administration.

J. Edward Kellough is Professor and Head of the Department of Public Administration and Policy at the University of Georgia. Dr. Kellough has published widely in public personnel management and public administration. Recent books include Understanding Affirmative Action: Politics, Discrimination, and the Search for Justice (Georgetown University Press, 2007). 